\title{
Correction to: Decellularization and Recellularization of Rabbit Kidney Using Adipose-Derived Mesenchymal Stem Cells for Renal Tissue Engineering
}

\author{
Shabnam Sabetkish ${ }^{1} \cdot$ Nastaran Sabetkish $^{1} \cdot$ Masoumeh Ekhtiari $^{1} \cdot$ Bahareh Mohammadi Jobani $^{1} \cdot$ \\ Abdol-Mohammad Kajbafzadeh ${ }^{1}$
}

Published online: 14 June 2021

(C) The Regenerative Engineering Society 2021

Correction to: Regenerative Engineering and Translational Medicine (2020) 6:433-441 https://doi.org/10.1007/s40883-020-00177-9

An author's name was incorrectly listed in this paper originally; the paper has been corrected online, and the author listing above is the correct one.

Publisher's Note Springer Nature remains neutral with regard to jurisdictional claims in published maps and institutional affiliations.

The online version of the original article can be found at https://oi.org/ 10.1007/s40883-020-00177-9

\footnotetext{
Abdol-Mohammad Kajbafzadeh

kajbafzd@sina.tums.ac.ir

1 Pediatric Urology and Regenerative Medicine Research Center,

Section of Tissue Engineering and Stem Cells Therapy, Tehran, Iran
} 